\title{
Kristevan Femininity and Negative Theology in Christopher Marlowe's Tamburlaine, I and II
}

\author{
by Tina Takapoui
}

\section{Introduction}

Christopher Marlowe has always been notoriously known as the alien, atheist, and sodomite dramatist of Elizabethan times, especially when shrouded in the shadow of his contemporary poet/playwright, William Shakespeare, whose works eventually pressed the maintaining the 'Self' of the Tudor monarchy. While the latter's literary output would represent the norms of the societal subjecthood, Marlowe's would unveil its suppressed unconscious. The present study would read Marlowe's Tamburlaine, Part I and II in the light of feminine as well as theological diversity that supplant the certainty of the dominant ideology of patriarchy of the then society. The veiled undercurrent of femininity as defined by Julia Kristeva in the manifestation of Otherness will be found associated with the presence of Elizabeth Tudor, the unmarried queen as a potential threat to certain power points of an essentially patriarchal society.

\section{Historical Background}

In his Tamburlaine, Marlowe chooses the historical, outlandish, Scythian Timur whose vices are "monumental and fundamental" and in line with the same propensity found in his other works (Simkin 48). The identity of the historical Timur's has been floating throughout history and literature, from "a potential saviour," to a "Persian robber," to "a cultural hero for Uzbak nationalists" with his immortal fame in Tonybee's words incomparable to any "other non-European historical figure ... in Western drama" (Knobler $101,108,112)$. His shifting, unfixed character could have been suitably exposed to the torrents of "political relationship between Britain and Central and South Asia" during the time of Elizabeth and Marlowe (102-3). Despite historically known as an ardent Muslim, he was simultaneously known as a threat to the world of Islam than a member of it; the "Timur of the Elizabethan and Stuart eras" was viewed as "an agent for the Christians;" as put in Whetstone's English Myrror, it was more beneficial to the British Empire 
to imagine "Timur to be the equal of any . . . classical antiquity" who deserved no less than praise (qtd. in Knobler 104). Marlowe's Tamburlaine is described as "the consummate virtuous 'Other" whose authoritative manner was modelled to put the leaders of the time to shame (105). In line with such Otherness, Marlowe's Tamburlaine would present alternative views towards the abject femininity not merely depicted in the figure of the female characters but in the violent upheaval of his dramatic world, in addition to the theological melange which defies belief in the presence of any religious prevalence.

\section{The Corporeal Site of Abject, Violence, and Death}

Violence as an essential part of Marlowe's works is ideologically tied to religion. The ontological discordance between the greatness of the world within and the baseness of the one without is one major account for Tamburlaine's commitment to violence, deaths and abject scenes of corpses on the scene. Despite the fact that Tamburlaine takes off the imposed identical garb of his pastoral life associated with "earth, fertility, and animals," he is firmly tied to his origin and its defiance is the fruition of a wholly imposed, patriarchal discourse (Moore 131). Marlowe's faith in "the ontological ... evil of matter" is shown on the stage by rotting abject corpses; the ruining world he creates wherever he goes further emphasises his urge against the totality of the body and the need to get over its confines, the backward movement with the desire to reach the Kristevan pre-Thetic unity with the universe now in chaos, and that considered, there can be no way to get round it (Moore 135). For Tamburlaine the partial destruction of the world cannot suffice; he seeks its holistic destruction to get to the core of what is abjected in Father's realm. Not bothering to justify his brutal acts, Tamburlaine's images of success and glory assume more blood and violence; the images of savage deaths and bloody tortures abound in Part II especially following "his protocol of white, red, and black banners" (McJannet 76). The self-proclaimed 'scourge and wrath of God' helps himself in bloody acts only for in so doing, he never feels 
objected by gods; they would instead "behold / Their scourge and terror tread on emperors" (1 Tam. 4.2.31-32).

Tamburlaine inevitably exits in old ages, never properly punished. His dying moments carry his ever rebellious ambitions of conquests "Give me a map; then let me see how much / Is left for me to conquer all the world," feeling remorseful of dying "and this unconquered" (2 Tam. 5.3.124-125, 159). He conceives of the world in terms of the confines of the visibility of the map "translating the unknown regions into nameable ... units" (Liao 37). Tamburlaine is "finally defeated by his 'servant' Death" when he becomes the "'monarch of the earth" (qtd. in Simkin 190). Contrary to the eternal life promised in Islam as an Abrahamic religion, "death in Marlowe is final" and unlike the contemporary works like Shakespeare's, no ghosts keeps haunting the quick, nor gods powerful enough to interfere in the course of events (Hopkins, Renaissance Dramatist 115). While Tamburlaine's blasphemy on the Koran is frequently interpreted as the main cause of his sudden ailment and death, it comes to him more as a gift, than the revenge of the enemies and carries him away not even once defeated by them and besides, his sons are then left to continue his empery.

Bajazeth's death yet, is shrouded within the feminine darkness of the pronoun "her" and the natural elements of disorder like "mists" and "winds" mentioned in addition to Death's chariot pulled by "her horses" (1 Tam. 5.2.226, 228, 229). Death is referred to as a "Rebellious" 'she' and distinguished from the horrible image of the Christian Angel of Death that Marlowe constantly shuns (1 Tam. 5.1.298). Jove's mythical weapon, 'thunderclap,' has now fallen in the hands of a feminine life-taker who is dragging the sanity of the great Turkish Sultan away from him. The moments are distant from the fame and nobility he once enjoyed living; Zenocrate in sympathizing with him and Zabina, remembers the heaven "that gave them honour at their birth/ and let them die a death so barbarous" (1 Tam. 5.1.350-51). The death moments, the reversed forms of child-labouring, are when the earth claims her child back to her womb; "Techelles draws his 
sword 'And wound the earth, that it may cleave in twain', so that they ... take ... revenge on the Fates for depriving him of his beloved"” and describes it as "an 'eyeless monster that torments my soul" (2 Tam. 2.4.97, 217-18, Simkin 192). Death eventually, reveals its function as the realm of unconscious, total abandonment of the domain of the known and the drowning into the continent of darkness, the preconscious realm of the womb and the triumph of the feminine atemporal space. While Tamburlaine's eventual ailing condition is presumed to be a "punishment for his presumption and ... persistent blasphemies" and "a sudden attack" by his lifelong alliance, Death, his final moments of suffering seem to be only an easy way out of the predicament he deserves to face rather than a just retaliation. His final moments promise the ease and quiet of the preverbal life in the warmth of the maternal womb, where the child rests in peace of the verbal silence. Death in both parts of the play, specifically the second, means nothing but excess, brutality, and deletion of consciousness, the same Medieval equivalent of 'sexual orgasm,' the Derridean indefinable, and Kristevan jouissance, and Marlowe better than any other Renaissance playwright is able to pen and draw it.

Body, the Maternal Site of Power

The world of matter to Tamburlaine, is reminiscent of the tragedy of the original loss of tranquillity, the beginning moment of "removal from the perfection and tranquillity of the divine," the disintegration and collapse of "one's true origin;" and the eventual "alienation of life" (Moore 129). The longing for such a world reminds one of the Choric unity prior to the child's entrance to the Thetic realm of symbol as the subject to the Law. Tamburlaine simultaneously feels the hatred and love to the material world which is "not even the creation of the true God; rather . . . the work of an inferior god, himself the result of an error in the divine realm" (Moore 128). He reflects such feelings to his as well as others' body once he conquers "others' bodies with his sword" and also "wounds himself" and the discursive efforts to get round the total separation of the material include "rape, murder, and the burning of towns" during which he 
attempts to achieve a runaway from the totality and separation of 'being' than to claim control of the self as well as of the society (Moore 132).

Tamburlaine's acts get more atrocious as the body of society is caught by insanity and brutality. His atrocity relies indubitably on "others' sense of loss" and to this end he manipulates "human body" as a site of power, micro, rather than macro power. Beyond theology, his triumph according to Shepard is "over some specific part of an opponents' body- his heart or his bowels" (qtd. in Liao 28). Yet, his advancement to their bodies has much resemblance to Bakhtinian grotesque body. As the site of power, Bakhtin's "high and low cultures" are closely associated with parts of body; the grand narratives and "the upper social class, as the upper parts of the body," are expected to be determinately "stable and fixed" while lying their power "upon ancestry" and history (Liao 29). In Tamburlaine, Part I also, Mycetes swears "by this my royal seat" upon which Cosroe puns in his reply "You may do well to kiss it then," a typical irreverence of Marlowe's (1.1.97-8). On the other hand, the lower social classes are in accordance with the fluctuations and mobility of the lower parts of the body, "a more subversive and destructive power than the fixed," the pillars upon which the Christian society is built (29). Tamburlaine enslaves his royal foes to that status of 'slaves,' 'steed to pull his chariot,' or even 'footstool' which in comparison to the actions he himself takes in the course of both parts of the rightfully play appear as such in their deeds and in so doing rids them all of their associations with the upper parts of the body. Symbolically, toppling the head of the society, Tamburlaine turns the body of society upside down which welcomes the Original Chaos of disorder and instability.

The instability of the upper part of the body of society is brought about with the "death of Mycetes, Cosroe, Arabia" which in turn has been mainly due to Mycetes' lack of stately efficiency, Sigismund's betrayal, Agydas's suicide, Bajazeth and Zabina braining themselves to death, the slaughter of the virgins of Damascus, filicide of Calyphas and stabbing of Olympia, and eventually "chaining and 
murdering of Babylon" to mention just a few instances (Liao 29). The fluctuation and unrest expected from the lower part is just happening where it is not supposed to, that is on the top; the head of society being captured by chaos, disorder, and madness. The reader may suitably imagine the Renaissance redefinition of Man, tossing and turning within the womb of Chaos with his head turned down to come to a world of different essence. One may observe him with all the abject defecation of the lower part corrupting the top position.

Tamburlaine is believed to have the sole desire for crown and earthly states; but this sounds a bit fishy, for what is desired, is not yet conquered, in the massive view of blood. The undercurrent longing for the maternal has found several instances throughout the play. "In burning Larissa, destroying Babylon and drowning its entire population," Tamburlaine is apocalyptically anguished to bring the world to its end. He compares his desiring self to Phaethon, the son of Helios and Clymene, with whose father's identity long-remaining a mystery, eventually changed the course of the father's "across the vaults of heaven" and "risked setting fire to [Mother] Earth" endangering the realm of the sky (Grimal 344). Eventually struck down by Zeus (the Father), his pyromania in the archetypal duality of Earth/ feminine and sky/masculine shows the threat of tendency to the Mater (Grimal 344). Tamburlaine's inclination towards the feminine is shown in seeking a way out of the material confines while Zenocrate remains one of his major motives as well as winnings to the end of her days. Tamburlaine's success in tyranny absolutely depends on her who in turn, is tightly attached to the world of matter/maternal, for, she is concerned about those "individuals who live, play, love, marry, and raise children" (Moore 134). Zenocrate is the core of Tamburlaine contrasting attraction and repulsion towards the material. In this sense, earthly crowns to him, are but childish toys; "he steals them, plays with them [and] rhapsodize over them . . . they symbolize the drive for his earthly omnipotence" and reminds one of the child amused by the lulling moments of the world of the mater-mother (Moore 133). Such coexisting attachment and detachment-that re- 
minds the reader/audience of the playful child when a toy interests and a few moments later bores him just the same-from the world of matter is not exclusive to Tamburlaine; it is in fact, a common taste in all Marlovian protagonists. Another example of Tamburlaine's desire for the indulgence in the warmth of the wombish blood, is his preoccupation with the act of drowning the enemies-including his own son-within "the sea of blood" (2 Tam. 5.2.13). As the King of Natolia finds distinction in Tamburlaine's murder of his son and their own, he does make the losers "wade up to the chin in blood" and the king of Amasia recalls him as "a monster that hath drunke a sea of blood;" and in this respect, Calyphas is no exception to his rule (2 Tam. 5.2.13). The very deed makes an ally of Death siding with the maternal to aid Tamburlaine on his way back to the 'Real' unity of the M/Otherland.

Tamburlaine, the detached self from the maternal, with no reconciliation between soul and matter-in the abjection of the maternal-remains but the shadow of a vain hope and Marlowe surfaces his sorrow about Tamburlaine's final minutes when his "blood is dried" and his artiers: "Are parch'd and void of spirit, that the soul, / Wanting those organons by which it moves / Cannot endure, by argument of art" ( 2 Tam. 5.3.95-98). Conforming to Marlowe's destined natural death, Tamburlaine longs to return to his mother town, Samarcanda towards the ends of Part II, in "golden armour like the sun;" where the authority of the maternal origin is no less powerful than patriarchy, to find the choric unity, harmony, and peace in the bosoms of the Mother (2 Tam. 4.3.116).

\section{Madness, Chaos, and Disorder, the Realm of the Feminine}

Marlowe's plays are most well remembered for their reluctance to favour domestic as well as womanish atmosphere. In their rare presence, women in Tamburlaine the Great, like his other plays, are linked to "sin, death, fall, and trouble-making" and limited to "the domestic sphere" under the light of constant male gaze and this has been acknowledged by his critics in the centuries after his own time (Liao 
40). His plays do not often assign shining roles to female characters despite the confines of femininity that is recovered in his plays; e.g. Tamburlaine's beloved Zenocrate is more deified than loved by him and for critics like Simkin, this is indicative of Marlowe's own alleged homosexual inclinations. Taken even in this respect there is an evident opposition between womanhood and femininity, the latter to refer to some condition of Otherness and exclusion from the realm of the Self.

In both parts the reader comes across binary oppositions of masculinity/femininity, Self/Other, speech/silence, theism/atheism, and superiority/inferiority. Some, if not all, are obvious oppositions justly taken for granted. The female characters supposedly associated with passivity and silence gradually assume more valour and power as one gives place to another. Sarah Emsley suggests that one of Marlowe's preoccupations has been "the balance between the masculine and feminine principles within the human psyche" (qtd. in Liao 41). Sarah Munson Deats also supposes that the "gender performances of Tamburlaine and Zenocrate in Part I . . [as indicative of the] dichotomizing of femininity and masculinity" are not really as opposed as the play apparently suggests. The attributes generally granted to masculinity and femininity, are the floating features that in the course of the two parts linger within the gender spectrum from one side to the other, giving way to the confusion of the gender-oriented power possibly rooted in the vague person of Queen Elizabeth's whose "masculine ruling style" necessitated by her reigning position forced an ambiguity of her feminine personality (Liao 42).

Regardless of the apparent strength and militarism, critics find something "effeminate about" Tamburlaine as well as Bajazeth, their masculinity more embattled than secured in the insistent rejection of femininity: The references of "black streamers in the firmaments" or "the sky shall wax as red as blood" made in both parts of Tamburlaine are the instances for the gender/power ambiguity of Marlowe's fused worlds where there can no clear-cut borderlines be found between the micro- and macrocosm, the realm of the original, feminine chaos (2 Tam. 5.3.49, 1 Tam. 4.2.53). 
Bajazeth's defeat is presented in the blurred, dramatic scene of $\mathrm{Za}$ bina's insanity "with grief and shame" while the two men's vaunting is manifested in their wive's mutual insults. The conflict between the two women is a mockery of the male zone, Zenocrate taking the same disdainful and ironical conversational tone and Zabina the superior look. Tamburlaine effeminates the army of the enemy assimilating the "Turkish soldiers as "flocks of fearful roes'," the softness of his tone "enhanced by ... . 'f' and 's' sounds" while "Zabina's invocation" is rather "violent" in asking Mahomet's God to "'make him rain down murdering shot from heaven / To dash the Scythians' brains, and strike them dead"' (Simkin 136). The narrative of the text, i.e. the stage directions, informs the reader that the "battle' is 'short" and the haste in overcoming Bajazeth while being dramatically licensed may also be "a testimony to Tamburlaine's skill and might" as well as the effort to emasculate an act that is firmly connected to the domain of the male.

On the other hand the female figures, Zenocrate, Zabina, and Olympia, die; but their deaths weave a tapestry of varied kinds though on the surface they are all negatively "muted and excluded" (Liao 42). Zenocrate chooses to fall completely obedient; yet so long as she lives, she functions as a haloed idol rather than a real entity, some dark space on Tamburlaine's map to conquer, yet for others a detached inaccessible piece of land, forever detached and intact, fetishized as a territory of an empire, "a silent corpse" (52). In Tamburlaine's eyes she is no less graceful than Helen:

Zenocrate's beauty as an invisible destructive source, remains as a source of inspiration for Tamburlaine to conquer more of the world and leave them in ruin for the rest of the play, her silence destabilizing the husband's urging assuredness for destruction. For Zabina death remains the only way to keep the remainder of her honour; as for Olympia "an autonomous female" figurine of unsubmissiveness, death is the ultimate way to absolute power and "resistance to the dominant," whereas yielding to life would mean nothing but surrender (Liao 61). 
Emsley believes that no matter how Zenocrate's submission serves Tamburlaine's power, the result is wasted given that "Olympia's rejections ... signal the decline of [Tamburlaine's] complete control over empire" (qtd. in Liao 61).

Meanwhile, much of the feminine tone is crawling beneath the martial scenes; for example, despite verbally aggrandizing his army, Bajazeth additionally but not willingly, renders its might and terror feminine quality by the analogy he makes between the body of his army and the image of Hydra which by no means carries androcentric manifestation of power: Hydra, a female monster brought up under a tree by Hera (herself the greatest goddess of Olympus) as a snake with several allegedly human heads giving off a reeking venomous and mortal smell "ravag[ing] the countryside" (Grimal 186). Her heads essentially managed to re-grow after being cut off by Hercules. The only way to stop the growth of her heads was to cut and bury the main head and also, set fire on the grooves and nature nearby. Bajazeth correlates the undefeatable strength of his army to the resistant nature of Hydra's heads which takes a Hercules to afford winning her; yet, in such effeminate militarism he does not give away the power from his men, but adds better horror to it.

Zenocrate is praised highly by Tamburlaine yet, only in his soliloquies and never indeed, in front of his public. It is also in his soliloquies where Tamburlaine reveals how he "suffers from his feminine nature" and effeminate thoughts (45). Calyphas's behaviour is assimilated to that of a traitor and a traitor need duly be punished. Yet, the removal of the feminine does not heighten the presence of the masculine; neither does it neutralize the effect of what is not visible. The power of the feminine like the Freudian famous iceberg remains as the bed of all occasions to occur, the bed, the nutrient, the mother. This abject femininity cannot be veiled forever; it leaks out through the negative theology that prevails both parts of the play as well as the "negative titles . . . as fox, lion; thief, felon, vagabond; paltry, devilish, barbarous, bloody, proud, and cruel" by which Tamburlaine is known to his enemies (43). Kuriyama suggests that the elimination 
of femininity assumes shape in the slaughter of the Damascan virgins as well as the burning of Larissa with their "disturbing" images in Part $I$ (qtd. in Liao 43).

Tamburlaine comes from Scythia, which was the original haunt of the Amazons, and Ann Rosalind Jones and Peter Stallybrass have recently pointed to the classical tradition of regarding Scythians as effeminate and prone to impotence and possible pederasty; Herodotus recounted how they succumbed to "the Scythian disease," defined as "the atrophy of the male organs of generation, accompanied by the loss of masculine attributes" ' (Jones and Stallybrass qtd. in Hopkins 133-34). In this sense, Mycetes, the weak King of Persia mirrors Tamburlaine's femininity he has attempted to suppress; something of Mycetes is inherent in Tamburlaine which makes the two, others for one another's' selves. The physical description of Tamburlaine is also close to the feminine speculation of a person watching their reflection in the mirror suffering the gaze of the society, "a 'blazon'-description of physical beauties, associated with ... idealised mistress of ... Petrarchan sonnet" (Hopkins 135):

So much of the feminine essence sought, is thus found in the person Tamburlaine himself. Referred to as "... damned monster, nay a feend of Hell" by King of Jerusalem he turns to the whorish figurine of femininity (2 Tam. 4.1.168). The fiendish character of Tamburlaine prompts the infernal Sin of Milton's, or Beowulf's fiendish monstress, Grendel's mother. Such associations are closer to the discourse of Mother than the patriarchal theism of the Roman Catholicism. Rejecting his own feminine side, Tamburlaine is determined to "create his own myth," for not only does femininity imply dependence, but is also "a representative of all that masculinity rejects;" the abject femininity, unconscious and uncertainty (Liao 43).

Marlowe is "interested in questioning ... the frontiers of" the known, believed-in world of the expected and illustrates his doubts in lack of firm religious faith of the "transgressive heroes;" this is what he attempts to reveal in the juxtaposition of the public and the private space which turns the severity and victory of the male-dominated 
space of the battlefield into the farcical carnivalesque festivity of the familial atmosphere (Hopkins 106). To this end he struggles with the theatrical space and as Greenblatt regards, is "drawn to ... the physical movement . . . within ... the confines of . . . the theatre" as an Elizabethan space which would "offer imaginative representations of areas ... never ... visited” (qtd. in Hopkins 106).

In the course of the two plays there is an undercurrent movement from the public space into "private, family-oriented" one, from the open space to an enclosed one with the warm promise of security (Hopkins, Renaissance Dramatist 24). "Familial interactions" and "social injustice and malaise" tightly join hands each to mirror the occurrences within the other realm; Part I of Tamburlaine "both opens and closes with families" with obvious conflicts found between the Persian royal family at the outset of the play, i.e. between Mycetes, and his brother, Cosroe when it come to the "questions of heredity, family resemblances and the nature/nurture debate" and eventually lead to the fragmentation of the royal family (Hopkins, "Fissured Families"). When Mycetes's crown is handed over to Tamburlaine the joy of the victory of a sudden, shifts from the public sphere to the chattering of friends and allies in the private; it is interesting to notice that the struggle over power, "the ripest fruit of all, / That perfect bliss and sole felicity, / The sweet fruition of an earthly crown" are celebrated in the confines of the private (1 Tam. 2.7.27-9). This is further pressed when it comes to the marriage of the Scythian shepherd that closes the play in a comic rather than tragic manner. Traditionally, a daughter of a family never enjoyed any condition other than the threat of "a diplomatic marriage" as Zenocrate did "before her capture by Tamburlaine;" her captivity by Tamburlaine can in fact turn out as her runaway from the force of the patriarchal society she is doomed to live in (Hopkins, "Fissured Families"). Zenocrate will no longer suffer the fate of a property won in the battle, but enjoys the reunion with her father as the fruit of her disobedience from what is patriarchally forced upon her, the marriage of convenience with the King of Arabia. Ironically enough, the audience never witnesses the sort, 
in their lieu the domestic quarrel and the "verbal confrontation of their women" are heard (Liao 23). The row keeps on going between the two ladies and involves their attending maidens consequently. All the glory and majesty of the male-dominated battlefield falls into the parodic, verbal rivalry of the women.

Marlowe's focus upon the outbreak of battle is more on the priority of verbal interchange over actual clash; a tendency which verges on the feminine verbalization rather than masculine actualization. While the fighting scene occurs off-stage, the audience witnesses "women [in] the argument" both of whom "attempting to assert authority ... via imagined reconfigurations of the power relations ... between them" (Simkin 134). Tamburlaine seems to be terminating Part I of the play by reaching a full stop in solemnizing his and Zenocrate's marriage. As the play ends in the manner of comedy, one may hope for peace and reconciliation to prevail. Nevertheless, reconsidering Tamburlaine's "charge of ethnic exoticism" and taking his as "the representative of racial otherness," such hope may only be a naive interpretation, one that Marlowe cannot comfortably suffice to (Burnett 133).

\section{Theological Background, Mélange of Theisms in Tamburlaine} In late Tudor times, religion was still "central to people's everyday lives" and "deviations" of any kind were thought of as "heresy or atheism" while England, as was the condition with other Western European countries, was the battle ground for the conflicts between the Roman Catholics with their "old superstition", and the newly emerging Protestants (Simkin 77). Renaissance reformation had brought religious controversies to the surface; the fluctuating doubts in the old religion had motivated the English to consider Christ, as a mere "model of behaviour for the enlightened in his victory over sin, the body, and death;" one who could no longer "atone for human sin," and the sacraments highly valued in Catholicism became suspicious with the Bible valued as precious in so far as it offered the allegories of rebirth (Moore 144). 
It is not thus, far from reality to consider Marlowe as a Cambridge student of theology, to have been familiar/ized with new enlightening religious issues. Kocher, for instance, assumes that Marlowe, as "a serious thinker," with his atheistic suppositions of "Christ's homosexuality" and bawdy wit, was the first of the Elizabethan writers who presented "the rising 'revolutionary dissidence" which resulted in his assault to Christianity (qtd. in Woodworth 78, 79). Having such preview in mind, on the other hand, "most critics considered Marlowe sympathetic to his characters' desire for the infinite;" Bartels in describing Marlowe as "outrageously other," perpetuates the identification of the dramatist and his protagonists (Moore 148).

His drama bridged the old morality plays of Middle Ages and the newly rising theatrical performances of such uncertainties. Marlowe satirically reflected the then religious controversies within his plays, enriching them with religious terms: "the majesty of heaven,' 'holy pictures,' . . . kneeling, and . . . 'Grace';" "the idea of the Blessed Virgin Mary" in the Virgins of Damascus just to mention a few (Hopkins, Renaissance Dramatist 115). His drama always raised questions about "religious doctrine, faith, doubt and belief" with unorthodox views "on the relations between God and humankind," that are eventually dealt with no clear answers (Simkin 78).

Marlowe, thus, benefitted a great deal from the varied views regarding the historical Timur and reflected such identical uncertainties in the floating nature of Tamburlaine with the abundance of adjectival presentations and the deprivation of a decisive fixation. Associated with "a god of war" floating between the divine and human (1 Tam. 5.1.1), "some powers divine, or else infernal, mixed / Their angry seeds at his conception: / . . never sprung of human race' (1 Tam. 2.6.9-11), or "A monster of five hundred thousand heads, / Compact of rapine, piracy, and spoil ... [a] presumptuous beast" (1 Tam. 4.3.7-8, 15), his monstrosity is theologically in all manners deviates him from the dictates of the norm. Tamburlaine is infamously known to disavow the comfort of religious dependence. Both parts of Tamburlaine obsessively deal with words where theism is of utmost im- 
portance. "In its strange fashion," the play with its "self-serving" references to gods is a "deeply religious" one both in respect of blasphemy to them (Cope). Such attention to the matter is more of negative essence than affirmation of any version of it. Kołoszyc suggests that: Negative theology seeks to avoid the kind of speech that avoids God precisely by speaking too comfortably about God, while at the same time avoiding the kind of silence that is itself a form of avoidance, like the silence of all comfortable atheism.

(Kołoszyc 234-5)

Marlowe's metamorphosis of a historically devout Muslim to a pompous heretic implies "a conscious rejection of beliefs previously held" and the challenge with the classical gods (Simkin 82). Tamburlaine defies religious dependence of all kinds in his confrontation with people of varied religions throughout both parts of the play. Tamburlaine never asserts a clear faith in any theological beliefs just as the playwright himself, never does. In the course of the events his religious identity finds sharp edges with the Turks'. He steadfastly insists upon his religious difference with Bajazeth whenever he resorts to his Islamic damnation of the conqueror, claiming protection by some "chiefest god," while in the Turkish sultan's eyes he is right on equal terms with "the Christian miscreants" (1 Tam. 4.2.8, 3.3.236). Apparently siding with Christian hostility to his Eastern Muslim opponents, Tamburlaine demands 'Alcoran' as well as other religious books to be burned. The prophet of the Turks, Mahomet, fails his followers in giving a proportionate response to Tamburlaine's outrageous rhetoric as though he were either non-existent, or totally powerless. Mahomet for Tamburlaine is but a mere body of the ancient times myths mingled with Islam, a mere icon of theism of all kinds to be rid of, as a major paternal discourse and this eventually includes the deities of the ancient times as well. In the face of such melange Mahomet's will to revenge does not seem to found a firm causal relation on Tamburlaine's death.

Such disappointment though, is not exclusively Mahomet's, for the Christian Lord had also been already assumed to have sided 
with Orcanes, the Natolian king in his combat with the Hungarian Sigismund. Tamburlaine's original figure as a "devilish shepherd" is an ironical contrast to the images of both Moses and Christ, and his challenge against Jove whose name reminds the reader about the Hebrew Jehovah, also an inclusive blasphemy to poly- and monotheisms of all kinds (1 Tam. 2.6.1-2). Marlowe playfully inverts certain "religious iconography;" the shepherd tears off his garb "to reveal the armour," a mocking gesture of Christ's "transfiguration" into human body; his soldiers fill "empty veins with airy wine / That, being concocted, turns to crimson blood' (2 Tam. 3.2.108-9), ... a blasphemous parody of the consubstantiation of the Eucharist" (Hopkins, Renaissance Dramatist 117). What Marlowe does, is in fact a negative application of theological iconography which turns his play Tamburlaine into a parody of religiosity of any kind. Cutting his arm in front of his sons, Tamburlaine makes a parodic "remodelling of the transfigured Christ," turning the grand narrative of Christianity to a carnivalesque imitation. His longing to reduce the "world ... to a map," includes merging Self and Other into one whole being both geographically and theologically (1 Tam. 4.4.83-4). Religious systems are juxtaposed as well as twisted in acts like Tamburlaine's masochistic wounding that could be grotesquely allusive to Christ who atoned for Man's sin by his flesh and blood. Yet, such similarity ends here. Tamburlaine's followers and the audience admire him not as a Christfigure, but "for the super-humanity of one who by Christian values is detestable" with insufficient evidence for the playwright himself, to dissociate himself for his work.

There are different gods believed in Tamburlaine, Part I and II, all reminding the audience of "'a pantheistic immanence" (Levins qtd. in Burton 139).Tamburlaine blends both Christian and Muslim beliefs to dare Mahomet to oppose his deeds, to "Come down ... and work a miracle" after which he suggests Muslims should seek another god to have faith in for the present one stays paralyzed to Tamburlaine's might (2 Tam. 5.1.186). His words are reminiscent of Bajazeth's frustrated remembrance of "sleepy Mahomet!" furthered 
by Zabina's mournful declaration that there is "left no Mahomet, no God" (1 Tam. 3.3.269; 5.1.239). That presumably should make a clear borderline between the protagonist and the Turks. Nonetheless, never does he grant his audience the luxury of certainty; for, in his religious, floating identity, once he is supposed to have turned his back to Turkish religious beliefs, he suddenly "out-Turks" the Ottomans in other aspects of his manner like his savage filicide at the time known to be "characteristic of Turkish cruelty" (Burton 148). He is a believer of theism of all sorts, resorting to Islam at one moment, and turning back to it and facing Christians' Son of God at some other, believing "Christ or Mahomet hath been my friend" (2 Tam. 2.3.11), and calling Jove as his eventual ally and "the chiefest god" (1 Tam. 4.2.8). Tamburlaine himself, as the 'scourge' of that 'chiefest god' keeps both "defending and attacking Christendom;" the two opposing inclinations make him morally conditional when he easily shifts his "religious identity ... with the play's shifting circumstances" (Burton 139). He reveals violent antipathy to the social world of races and religions, be they Mahometan Turks or Christian Europeans or Egyptians. One may consider the chance of Marlowe not trying to draw a firm borderline between the Western Christians and the Eastern Muslims so as not to side with either, and instead create a conglomeration of varied religious discourses each standing opposed to the other(s), for Tamburlaine finally to be on better terms with ancient polytheism if not even totally respectful to it either.

In a manipulative fashion, Tamburlaine regards divinity as futile except for that which is adjustable to his own ends. In Tamburlaine, part II, Act 5, "he taunts Mahomet and identifies himself as the "scourge" of another higher God" (Moore 125). He finds the worship of such incapable god vain in the face of his sword which has "... sent millions of Turks to hell, / Slew all his priests, his kinsmen, and his friends," while himself remaining "untouched by Mahomet" (2 Tam. 5.1.179-180, 181). He feels disdainful for any "religion codified in books" and such disdain makes him defy the subjection of his flesh and blood to laws (Moore 126). His, becomes the unknowable 
whose will destines the being of the divines of the lesser degrees possible. Tamburlaine's religion is equated with a Machiavellian "religious ideology" as the core of his manipulative terrorism "creating a mass fear and panic based on something which may or may not happen" (Hopkins 120). Mad scenes, as borderline confusion, abound in both parts of Tamburlaine. Kings fall down to pull Tamburlaine's chariot, dash out their brains to death, burn their own bodies, cut their throats and all, embed the abject hostility toward their own corporeal essence. There is a thin "line between pathos and comedy in . . . staging of death" as is the case between how we define tyranny and mercy (Hopkins 108). As Bossert suggests, the tyrant never lives at a distance from us; he may be "a friend, a neighbour, or even the reader himself" and in this sense Marlowe manifests the very tyranny rooted in the basest of all hearts (Bossert 146-47).

Such scenes of utter horror are related to the abject of the post-choric space where the spectator cannot help witnessing the occurrence of something doleful despite their disgust and horror, those that Kristeva finds mesmerising in spite of the terror they embed. Tamburlaine's acts cannot be totally read as tyrannical for his simultaneous affection to Zenocrate as well as paying off the loyalty of the comrades. His sadistic acts seem more attractive than repellent in their utter barbarity. When Zenocrate witnesses "the streets strow'd with dissevered joints of men, and wounded bodies gasping yet for life," she is as mesmerized and horrified as the audience (1 Tam. 5.5.261-61). Moreover, while manslaughter appears reprehensible to the moral viewpoint of Zenocrate, she manages to clear her head off the matter and ally with Tamburlaine when her own father is spared. Tamburlaine and his allies' deeds cannot be confined within a specific realm of good or evil, just as the same story goes with the characters themselves. Concepts as affirmed or tabooed lose meanings as the bed for such certain definitions is shaken to the root and in such confusion none, including the audience seems to find their way to have a clear judgement of the abject and non-abject. 
Bajazeth on the other hand, flaunts superiority to his "contributory king[s]" by enslaving them though "in name only" (Bossert 147). He depicts the very Self of the Catholic Europe merely in a different outlook; "Many early modern English accounts of Turkish slavery observe the irony that the Grand Turk regards all the lesser Islamic kings as slaves" (Bossert 147 n.104). Bajazeth and his troops represent a blurred vision of the very Pope who, alongside with the realm of his power and followers, had started to be scrutinised. Marlowe disguises the Pope in the person of the Turkish Sultan, Bajazeth (his realm as that of the Old Christendom), both representing the evil of diversion from true Christianity; needless to say that true Christianity in Marlowe's time was the Reformation that was taking place within the Anglican Church (qtd. in Brown 41). Bajazeth could be the Pope enslaving the believers under the yoke of Catholic sacraments for Tamburlaine to redeem the Christian Everyman. For Marlowe then, Christianity loses its firm grounds of definition and turns to some true belief with no specific contours of prescribed obligations. By the same token, Marlowe's Tamburlaine may embody all the unorthodoxy that a 'Henry VIII person' or a descendent of his, was to overcome the corrupt Church in their deviation for its pathway. The Part I Tamburlaine in his enmity to Bajazeth acts as the protector of Europe in accordance with their mercantile interests in Eastern regions. One may relevantly be reminded of Henry VIII who once titled as 'the Defender of the Faith' by Pope, turned to a major threat to the Catholic Church); for in his assault to Natolia as the centre of the Ottoman Empire, "the Christians shall have peace" (2 Tam. 1.1.57). But, just as "Tamburlaine enters the second play a Muslim" later to refuse the simplicity of religious 'Self/Other' classification, he turns to an ideologically ambiguous entity in the conflict of replication of "the early dynamic of Part One" (Burton 145). Gazellus, the Christian viceroy of Byron, finds the Danube all "glutted with the Christians blood," and Tamburlaine an equal a threat to Turkish Empire and Europe (2 Tam. 1.1.14). 
Just as Marlovian Christianity loses its clarity of boundaries, Tamburlaine also, functions as a religious agent in perplexity. What creates a borderline between Tamburlaine and the rest of the characters is his exploitative avarice to shift towards different moral beliefs apt to a given condition, rather than a definite opposition of Islamic/ Christian views. More importantly, there is a general scope of a dual opposition between the Monotheism of Abrahamic religions and the Polytheism of the mythical gods, although Tamburlaine never assures the audience to remain faithful to either of them to the end. He seeks a "place within a global frame" functioning at one moment as a "redeemer" of Christianity and at the next, troubling it (Burton 139). There is an equality contained between Tamburlaine and his English Anglican counterpart, just as the Turks are assimilated to the continental Catholics who were at odd with the Elizabethan reign; he wills to "subdue the Turk, and then enlarge / Those Christian captives which" Bajazeth has so far kept "as slaves" (1 Tam . 3.2.46-47). His compassion with the Christian slaves may at first be interpreted as the religious difference between the Turks and the Christians; but gathering them all under the ancient Abrahamic religion, the very line may also refer to the Christian deviation which had started to spread all across Europe to shake the pillars of old Catholicism. Faith and the Rights of Marlowe's Tamburlaine

While Tamburlaine never disappoints his faithful allies, the God of the Christians, just in line with the protagonist's atheistic aspirations, remains ambivalently avaricious. He appears more willing to side with the Turks than to render support to His own believers when Sigismond, the Christian king of Hungary pays for his betrayal to the Turkish allies in the battle of Varna. The Christian Gazellus and Sigismund turn their backs to Orcanes, their recent ally, unlike Tamburlaine who never disappoints those like Theridamas who accept his might wholeheartedly and are unexceptionally rewarded for their loyalty. Orcanes denounces his foes as "traitors, villains, [and] damned Christians ... [that] care so little of their prophet Christ" as their oath by his name mean nothing to them (2 Tam. 2.2.29-35). The Muslim 
Orcanes prays to the Lord: "On Christ still let us crie- / If there be Christ, we shall have victorie" and ironically, He turns His back to the Hungarian believers (2 Tam. 2.2.63-64). The confusion of religious support is fundamentally shown in this conflict when the two former enemies, make a recent allegiance against the forces of Tamburlaine and to the surprise of the audience, Orcanes, the Muslim King of Natolia, owes victory over the treasonous Hungarian king to Christ, rather than Mahomet. In such confusion Christianity and Islam seem to reflect only one another both unanimously opposed to the atheistic views of Tamburlaine.

\section{Conclusion}

Tamburlaine, beyond good and evil, follows a lifestyle "exempt from servitude," a "Nietzschean superman," a hyperbolic overreacher, or a Machiavellian villain. In any case, he is certainly a borderline figure "at once super-human and all too human" in addition to his highlighted Elizabethan Otherness (1 Tam. 1.2.31; Cope). Being at once of a human, vicious, and heroic nature, with heartless and cruel deeds, Tamburlaine performs as a child born of Chaos, one who longs to return to the dark Feminine melange of disorder and madness while examining the sympathy of the audience. An agent of the "black Jove" Himself and the rootless son of savagery, he disregards the norms of all kinds of the Elizabethan patriarchal Law, right in line with the presence of the virgin Queen on the apex of the society $(2$ Tam. 5.1.98).

Tina Takapoui 


\section{Works Cited}

Bossert, A. R. The Golden Chain: Royal Slavery, Sovereignty and Servitude in Early Modern English Literature, 1550-1688. Maryland: University of Maryland, 2006. http://drum.lib.umd.edu/handle/1903/4120

Brown, William J. "Marlowe's Debasement of Bajazet: Fox's Actes and Monuments and Tamburlaine, Part I." Renaissance Quarterly (The University of Chicago Press on behalf of Renaissance Society of America) 24, no. 1 (Spring 1971): 38-48. http://www.jstor.org/ stable/2859339

BurnetT, Mark Thornton. "Tamburlaine the Great, Part One and Two." In Companion to Christopher Malowe, by Patrick Cheney, 127143. Cambridge: Cambridge University Press, 2006.

Burton, Jonathan. "Anglo-Ottoman Relations and the Image of the Turk in Tamburlaine." Journal of Medieval and Early Modern Studies (Academic Research Library) 30, no. 1 (Winter 2000): 125-134. http://muse.jhu.edu/login?uri=/journals/journal_of_medieval_and_ early_modern_studies/v030/30.1burton.pdf

Cope, David. Marlowe's Tamburlaine: Unsettling Audience Loyalties. 1996. http://web.grcc.cc.mi.us/english/shakespeare/ notes/Marlowe. PDF (accessed 8 9, 2011).

Grimal, Pierre. Concise Dictionary of Classical Mythology. Edited by Stephen Kershaw. Translated by A. R. Maxwell-Hyslop. Cambridge: Blackwell, 1990.

Hopkins, Lisa. Christopher Marlowe, Renaissance Dramatist. Edinburgh: Edinburgh University Press, 2008.

—. Fissured Families: a Motif in Marlowe's Plays. 1997. http:// freessays.0catch.com/marlowehopkins.html (accessed 8 9, 2011).

Knobler, Adam. "Timur the Trope." Medieval Encounters (The College of New Jersey Press) 7, no. 1 (2001): 101-112. http://www.ingentaconnect.com/content/brill/me/2001/00000007/00000001/ $\operatorname{art} 00004$ 
Liao, Shu-ying. Power and Women in Christopher Marlowe's Tamburlaine the Great. National Cheng Kung University Press, 2004. http:// etdncku.lib.ncku.edu.tw/theses/available/etd-0823104-144851/unrestricted/etd-0823104-144851.pdf

Marlowe, Christopher. Tamburlaine the Great, Part I. Vol. 1, in The Complete Works of Christopher Marlowe, by Fredson Bowers. Cambridge: Cambridge University Press, 1981.

Marlowe, Christopher. Tamburlaine, Part II. Vol. 1, in The Complete Works of Christopher Marlowe, by Fredson Bowers, 149-252. Cambridge: Cambridge University Press, 1981.

McJannet, Linda. The Sultan Speaks: Dialogue in English Plays and Histories about the Ottoman Turks. Hampshire: Palgrave Macmillan, 2006.

Moore, Roger E. "The Spirit and the Letter: Marlowe's 'Tamburlaine' and Elizabethan Religious Radicalism." Studies in Philology (University of North Carolina Press) 99, no. 2 (Spring 2002): 123151. www.jstor.org/stable/4174724

Simkin, Stevie. Marlowe: The Plays. Edited by Nicholas Marsh. Hampshire and New York: Palgrave Macmillan, 2001.

Woodworth, Marc. "The Tragic Mode of Christopher Marlowe's Tamburlaine Part I." A Journal of Medieval and Reniassance Studies (UC Publications) 16, no. 1 (1985): 77-86. http://escholarship.org/ uc/item/1z93087m 